Section Editor Mitchell S.V. Elkind, MD, MS

\title{
Teaching NeuroImages: Sacral spine chloroma
}

Figure 1 Intra-axial and extra-axial sacral chloroma

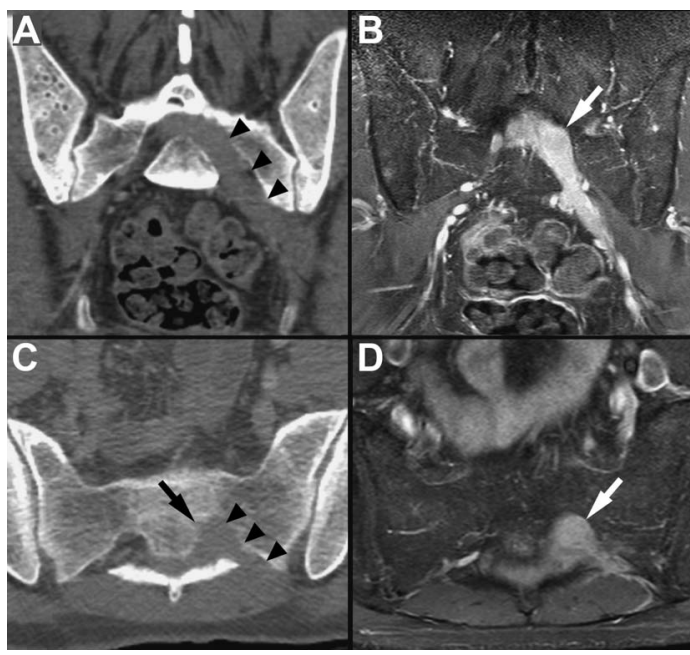

Coronal (A) and axial CT (C) images show left S2 nerve root enlargement (black arrowheads) with adjacent osseous erosion of the left S2 foramen (black arrow, C). Gadolinium-enhanced T1-weighted MRI with fat suppression shows corresponding sacral nerve root enhancement (white arrows) on coronal (B) and axial (D) images, consistent with sacral nerve chloroma.

A 23-year-old man with recurrent acute myeloid leukemia (AML) underwent successful reinduction and was judged posttherapy to be in complete remission. Soon thereafter, he complained of pain in his left buttock radiating into his left posterior thigh. Neurologic examination was unremarkable. Radiographic evaluation demonstrated a left S2 lesion suggestive of a nerve sheath tumor (figure 1). An open biopsy was performed that revealed a chloroma pathologically (figure 2), sometimes referred to as a myeloid sarcoma. ${ }^{1,2}$ Most chloromas are found in patients with recurrent AML and are overwhelmingly intracranial. ${ }^{1}$ Infrequently, chloromas are paraspinal, and in this location present with epidural spinal cord compression. ${ }^{2}$ Intraspinal invasion by a chloroma is rare. Systemic evaluation confirmed recurrent AML, for which he was successfully treated with reinduction and whole-body irradiation followed by an allogeneic
Figure 2 Medium- and high-power (inset) photomicrographs of a hematoxylin \& eosin-stained section of the sacral lesion

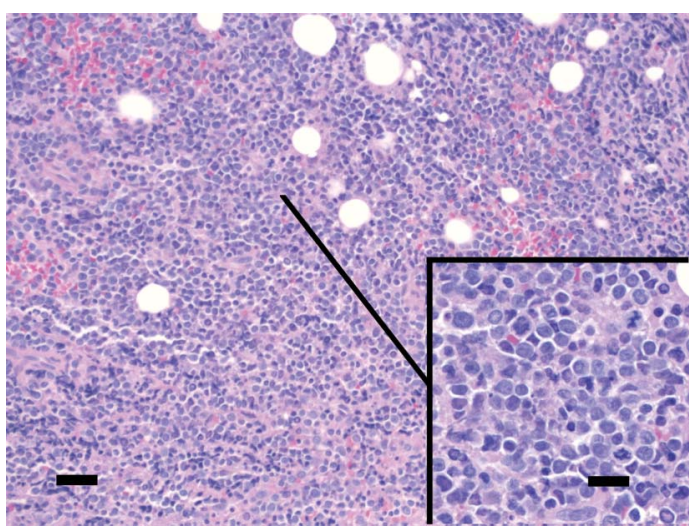

Note the high nuclear: cytoplasmic ratio, irregular nuclei, frequent apoptosis, and scattered mitotic figures. Scale bars: medium power $0.4 \mathrm{~mm}$; high power $20 \mu \mathrm{m}$.

transplant. He is currently disease-free and neurologically asymptomatic 1 year posttransplant.

\section{AUTHOR CONTRIBUTIONS}

Marc C. Chamberlain: drafting/revising the manuscript, study concept or design, analysis or interpretation of data, accepts responsibility for conduct of research and final approval, acquisition of data, study supervision. Trent L. Tredway: analysis or interpretation of data, accepts responsibility for conduct of research and final approval, acquisition of data. Don Born: analysis or interpretation of data, accepts responsibility for conduct of research and final approval, acquisition of data. James R. Fink: drafting/revising the manuscript, accepts responsibility for conduct of research and final approval.

\section{STUDY FUNDING}

No targeted funding reported.

\section{DISCLOSURE}

The authors report no disclosures relevant to the manuscript. Go to Neurology.org for full disclosures.

\section{REFERENCES}

1. Akhaddar A, Zyani M, Mikdame M, Boucetta M. Acute myeloid leukemia with brain involvement (chloroma). Intern Med 2011;50:535-536.

2. Bakst R, Wolden S, Yahalom J. Radiation therapy for chloroma (granulocytic sarcoma). Int J Radiat Oncol Biol Phys 2012;82: 1816-1822.
Download teaching slides: www.neurology.org 


\title{
Neurology
}

\author{
Teaching NeuroImages: Sacral spine chloroma \\ Marc C. Chamberlain, Trent L. Tredway, Donald Born, et al. \\ Neurology 2013;81;e87 \\ DOI 10.1212/WNL.0b013e3182a43aed
}

This information is current as of September 9, 2013

\begin{tabular}{|c|c|}
\hline $\begin{array}{l}\text { Updated Information \& } \\
\text { Services }\end{array}$ & $\begin{array}{l}\text { including high resolution figures, can be found at: } \\
\text { http://n.neurology.org/content/81/11/e87.full }\end{array}$ \\
\hline Supplementary Material & $\begin{array}{l}\text { Supplementary material can be found at: } \\
\text { http://n.neurology.org/content/suppl/2013/09/08/81.11.e87.DC1 }\end{array}$ \\
\hline References & $\begin{array}{l}\text { This article cites } 2 \text { articles, } 0 \text { of which you can access for free at: } \\
\text { http://n.neurology.org/content/81/11/e87.full\#ref-list-1 }\end{array}$ \\
\hline Subspecialty Collections & $\begin{array}{l}\text { This article, along with others on similar topics, appears in the } \\
\text { following collection(s): } \\
\text { All Imaging } \\
\text { http://n.neurology.org/cgi/collection/all_imaging } \\
\text { All Oncology } \\
\text { http://n.neurology.org/cgi/collection/all_oncology } \\
\text { All Spinal Cord } \\
\text { http://n.neurology.org/cgi/collection/all_spinal_cord } \\
\text { Metastatic tumor } \\
\text { http://n.neurology.org/cgi/collection/metastatic_tumor } \\
\text { Nerve tumor } \\
\text { http://n.neurology.org/cgi/collection/nerve_tumor }\end{array}$ \\
\hline Permissions \& Licensing & $\begin{array}{l}\text { Information about reproducing this article in parts (figures,tables) or in } \\
\text { its entirety can be found online at: } \\
\text { http://www.neurology.org/about/about_the_journal\#permissions }\end{array}$ \\
\hline Reprints & $\begin{array}{l}\text { Information about ordering reprints can be found online: } \\
\text { http://n.neurology.org/subscribers/advertise }\end{array}$ \\
\hline
\end{tabular}

Neurology ${ }^{\circledR}$ is the official journal of the American Academy of Neurology. Published continuously since 1951, it is now a weekly with 48 issues per year. Copyright (C 2013 American Academy of Neurology. All rights reserved. Print ISSN: 0028-3878. Online ISSN: 1526-632X.

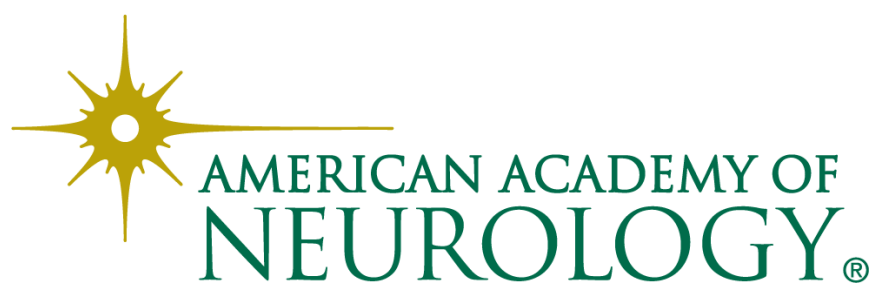

